\title{
Vasectomy in Spotted Paca (Cuniculus paca)
}

\author{
Felipe Farias Pereira da Câmara Barros ${ }^{1,3}$, Pedro Paulo Maia Teixeira ${ }^{1,2}$, Maria Eduarda Basto Andrade \\ Moutinho da Conceição ${ }^{3}$, Ricardo Andres Ramirez Uscategui ${ }^{3}$, Leandro Nassar Coutinho ${ }^{3,4}$, Marina Botelho \\ Soares Brito ${ }^{3}$, Aline Eyko Kawanami ${ }^{3}$ \& Wilter Ricardo Russiano Vicente ${ }^{3,4}$
}

\begin{abstract}
Background: Cuniculus paca is the second largest neotropical rodent. It is not endangered, but your habitat has been destroyed and the specie has been hunted, because of its prized meat. In this context captive breeding is an alternative to reduce the hunt. Then, adult male vasectomy is an interesting alternative for Cuniculus paca since the animal does not lose libido and maintain cyclicity of females into the enclosure. This technique is a method of sterilization which the vas deferens is surgically clamped, cut, or otherwise sealed and thus prevents the release of sperm when a male ejaculates. The aim of this study was to describe the vasectomy technique on a male spotted paca kept in captive.

Case: A captive adult male of Cuniculus paca, lived in Brazilian wild fauna breeding for scientific research. It was maintained on precinct with no other animal, ate fruits, vegetables, tubers and rodent chow and water offered ad libitum. It was submitted to bilateral vasectomy to maintain reproductive behavior on bevy, but not impregnate females. The anaesthesia was performed using ketamine hydrochloride $(25 \mathrm{mg} / \mathrm{kg} \mathrm{IM})$ and midazolam $(0.5 \mathrm{mg} / \mathrm{kg} \mathrm{IM})$ as premedication, and isoflurane in open system by facemask diluted in $100 \% \mathrm{O}_{2}$ for induction and maintenance. Immediately after induction, was performed epidural anesthesia using $4 \mathrm{mg} / \mathrm{kg}$ of lidocaine hydrochloride without vasoconstrictor associated in the same syringe with $0.2 \mathrm{mg} / \mathrm{kg}$ of methadone hydrochloride to promote analgesia. As the testes in this species are inside the abdomen, the surgical approach was made by paraprepucial skin incision and ventral midline abdominal incision. After access the cavity, the testes were located and the vaginal tunics were incised to access the vas deferens. After exposed, both were doubly ligated, sectioned and removed a segment of approximately $1 \mathrm{~cm}$ of each duct. Finally, the occlusion of subcutaneous and muscle layers were made using 2-0 absorbable and skin with 2-0 non-absorbable sutures. Postoperatively, benzathine penicillin (30,000 IU/ $\mathrm{kg}$ IM once), tramadol ( $4 \mathrm{mg} / \mathrm{kg}$ IM once) and meloxicam ( $0.3 \mathrm{mg} / \mathrm{kg}$ SC SID for 3 days) were administered. Ten days post-surgery, the animal was fully recovered and after twenty days, it was transferred to enclosure of females. None were fertilized after vasectomy, and there was no change in reproductive behavior among individuals.

Discussion: Zoos and breeding have a problem when animal population increases too much, thus vasectomy is an important alternative to avoid this, because it does not lose sexual behavior, but cannot impregnate. The spotted paca presented intracavitary testicles without elevation Skin evidence to scrotum formation, however may also present inguinal regions testes beside penis or scrotum, most evident in reproductive season, similarly occurs in rats and agoutis. In the present case was performed bilaterally vasectomy to have satisfactory results for spermatogenesis reduction, confirming was indicated by some studies in rats and rabbits. Some studies in monkeys and rodents showed that after some time the spermatic cells decrease. In the present study sexual behavior and quality of patient ejaculate, were not completely monitor, to not interfere on management, but there was no female fertilized in a period of 1 year. This procedure showed to be feasible and an easy implementation for maintenance of the estrous cycle of females.
\end{abstract}

Keywords: Cuniculidae, reproduction, rodent, surgery, vas deferens. 


\section{INTRODUCTION}

Spotted paca is not endangered, according to the International Union for Conservation of Nature [16], although there no specimen in certain parts of its distribution due to habitat destruction [15] and poaching, once its meat is highly prized $[13,16]$. Thus, the use of captive breeding in this species is interesting since it could promote a reduction in hunting and trafficking pressure and also provide an alternative source of protein [10]. Positive factor to this is its good adaptability to captivity, which contributes directly to the research related to breeding, conservation purposes and improvement in zootecnical production [5].

In captivity, contraception techniques are often important for maintenance of males and females housed in the same enclosure. Vasectomy is a highly effective contraceptive method which can play an important role in reducing the growth of a population [18].

Moreover, it shows an excellent alternative in the breeding of wild species in captivity, keeping reproductive behavior of males and females. This surgical procedure leads to interruption of the passage of sperm through the vas deferens, by ligation, excision or section of part of these $[6,8,18]$.

Considering the few data in the literature, the aim of this study was to describe vasectomy technique in a captive spotted paca.

\section{CASE}

A male spotted paca, adult, kept in breeding specimens of Brazilian fauna for scientific purposes, recorded by the Brazilian Institute of Environment and Renewable Natural Resources (IBAMA, 482,508 record), underwent bilateral vasectomy in order not to change the its libido, keep the cyclicality of females and do not fertilize them. It was kept in an isolated cage, receiving daily handling similar to other animals, feeding on fruits, vegetables and various tubers, rodent chow, and water offered ad libitum.

For the surgical procedure, it was submitted to anesthesia by using ketamine (ketamina $\left.{ }^{\mathrm{TM}}\right)^{1}[25$ $\mathrm{mg} / \mathrm{kg} \mathrm{IM}]$ and midazolam (Dormonid $\left.{ }^{\mathrm{TM}}\right)^{2}[0.5 \mathrm{mg} /$ $\left.\mathrm{kg} \mathrm{IM]} \mathrm{as} \mathrm{premedication} \mathrm{and} \mathrm{isoflurane} \mathrm{(Isoforine}{ }^{\mathrm{TM}}\right)^{2}$ via face mask in an open system diluted in $100 \% \mathrm{O}_{2}$ for induction and maintenance.

Immediately after induction, epidural anesthesia was performed using $4 \mathrm{mg} / \mathrm{kg}$ of lidocaine hydrochloride (Lidovet $\left.{ }^{\mathrm{TM}}\right)^{3}$ without vasoconstrictor as- sociated in the same syringe with $0.2 \mathrm{mg} / \mathrm{kg}$ methadone hydrochloride (Mytedon $\left.{ }^{\mathrm{TM}}\right)^{2}$ to promote analgesia.

Animal was positioned in dorsal recumbency on a surgical table. As the testes in this species are located inside the abdominal cavity, the access was performed by incision in paraprepucial ventral skin of the abdomen. After access to the cavity, the testes were located and vaginal tunics were sectioned for location of the vas deferens (Figure 1). After exposure, both were doubly linked, sectioned and removed a segment of about $1 \mathrm{~cm}$ in length of each conduit (Figure 2).

Finally, the occlusion of muscle and subcutaneous layers were made using 2-0 absorbable and skin was closed with 2-0 non-absorbable sutures. Postoperatively, benzathine penicillin (Pronto $\left.\mathrm{Pen}^{\mathrm{TM}}\right)^{3}[30,000$ IU/kg IM once], tramadol (Tramadon $\left.{ }^{\mathrm{TM}}\right)^{2}$ [4 mg/kg IM once] and meloxicam $\left(\text { Maxicam }^{\mathrm{TM}}\right)^{4}[0.3 \mathrm{mg} / \mathrm{kg} \mathrm{SC}$ SID for 3 days] were administered.

Ten days post-surgery, the animal was fully recovered and after twenty days, it was transferred to enclosure of females. None were fertilized after vasectomy, and there was no change in reproductive behavior among individuals.

\section{DISCUSSION}

The no controlled population increase of captive animals is a problem faced by zoos and farms [19]. Thus, vasectomy is an interesting alternative in order to not lose the male libido. As long as androgens continue to be produced by the Leydig cells, keeps cyclicity in females, continuing the reproductive behavior in the group [6].

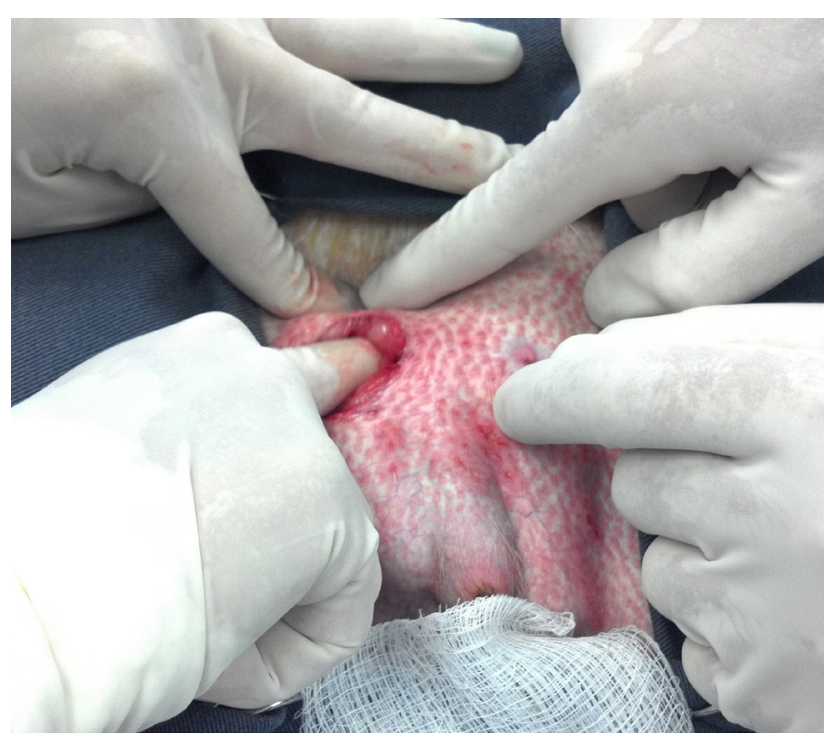

Figure 1. Vasectomy in Cuniculus paca. Ventral right paraprepucial access for vas deferens localization. 


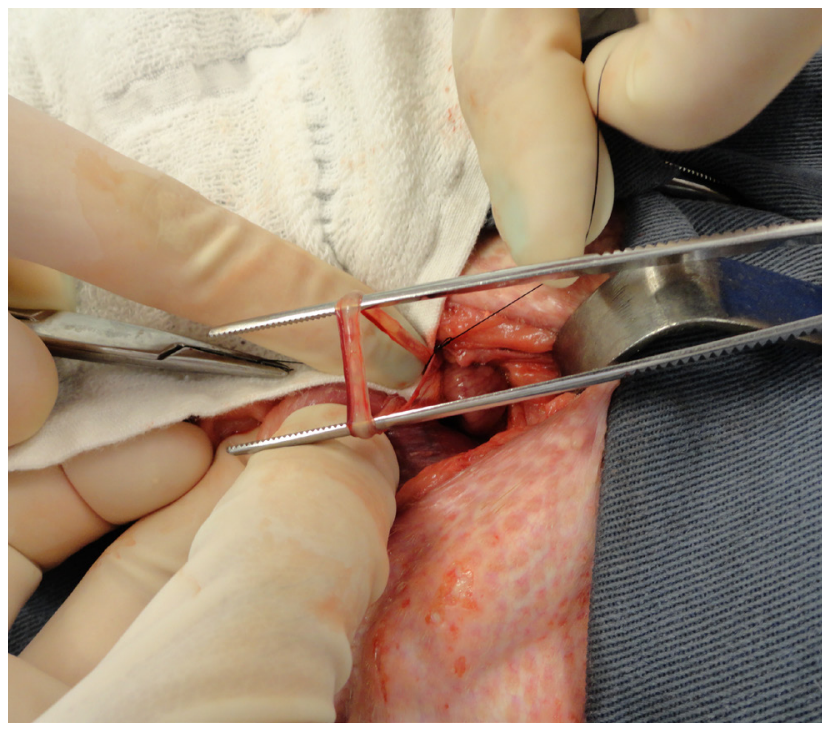

Figure 2. Vasectomy in Cuniculus paca. Exposure and link of the vas deferens.

The male presented intracavitary testicles without evidence of skin rise to the formation of the scrotum, but may also have the testicles in the inguinal regions beside to the penis or scrotum, most evident in the breeding season, just as occurs in rats and agoutis. The vas deferens was surrounded by the tunica vaginalis, cremaster muscle and was shown as a relatively straight tube having uniform diameter across the thread $[2,3,12]$.

In this case, it was performed bilateral vasectomy to get satisfactory results for reduction of spermatogenesis, as suggested for some studies in rabbits and rats $[8,11,14]$, however, other authors had reduced motility and sperm count in semen from both testes when done unilateral vasectomy on African giant rat (Gambianus cricetomys) [4] and mice [17].

In a study using capuchin monkeys (Cebus apella), after 105 postoperative days $100 \%$ of the animals showed a negative ejaculate for sperm cells [19]. It was observed testicular fibrosis in mice 12 to 16 months after vasectomy, resulting in infertility [17]. In another study, it was observed that surgery induced deterioration in the seminiferous tubules associated with increased DNA fragmentation in testicular cells [18]. In the present study we could not completely monitor the behavior and the quality of patient ejaculate, to not interfere on the handling, but there was no female fertilized in a period of 1 year. However, some studies in rodents showed that decreasing in testosterone levels occurs eight weeks after vasectomy [4].

The decrease in the number and sperm motility occurs because developing anti-sperm autoantibody $[17,20]$. It happens gradually, and we should avoid placing the male with breeding females soon after surgery [19]. There are also sperm granuloma formation at the vasectomy site and orchitis that contribute to infertility, as well as oxidative stress that leads to apoptosis, but no one knows for sure the pathogenesis of post-vasectomy infertility [1,9].

Sperm granuloma formation is directly linked to the effective reduction of spermatogenesis. In rats, spermatogenic damage depends mainly on the postoperative development of the sperm granuloma, thus when granuloma formation is small or when there was no formation, sperm production should be significantly low [11].

Overall, we can conclude this procedure proved to be feasible and suggests an easy alternative for the management of males and females kept in the same enclosure, without gonadectomy.

\section{MANUFACTURERS}

${ }^{1}$ Schering-Plough. São Paulo, SP, Brazil.

${ }^{2}$ Laboratório Cristália. São Paulo, SP, Brazil.

${ }^{3}$ Bravet. São Paulo, SP, Brazil.

${ }^{4}$ Eurofarma Laboratórios S.A. Ribeirão Preto, SP, Brazil.

Acknowledgements. The authors would like thank FAPESP and CNPq for their support in the study.

Declaration of interest. The authors report no conflicts of interest. The authors alone are responsible for the content and writing of the paper.

\section{REFERENCES}

1 Adams C.E. \& Wald M. 2009. Risks and complications of vasectomy. Urology Clinic North America. 6: 331-336. 2 Borges E.M., Branco E., Lima A.R., Leal L.M., Martins L.L., Reis A.C.G., Cruz C., Machado M.R.F. \& Miglino M.A. 2013. Morfologia e topografia dos órgãos genitais masculinos externos da paca (Cuniculus paca, Linnaeus, 1766). Biotemas. 26(4): 209-220.

3 Chiasson R.B. 1969. Laboratory Anatomy of the White Rat. 2nd edn. Arizona: Wm. C. Brown, 81 p.

4 Duru F.I.O., Ajayi S. \& Azu O.O. 2013. The effect of unilateral vasectomy on testosterone and testicular parameters in the adult male African giant rat (Cricetomys gambianus). African Health Sciences. 13(2): 483-489. 
5 Guimarães D.A.A., Bastos L.V., Ferreira A.C.S., Luz-Ramos L.S., Ohashi O.M. \& Ribeiro H.L. 2008. Características reprodutivas da paca fêmea (Agouti paca) criada em cativeiro. Acta Amazonica. 38(3): 531-538.

6 Hedlund D.A. 2007. Cirurgia dos sistemas reprodutivo e genital. In: Fossum T.W. (Ed). Cirurgia de Pequenos Animais. 3.ed. São Paulo: Roca, pp.571- 637.

7 Kong L.S., Huang A.P., Deng X.Z. \& Yang Z.W. 2004. Quantitative (stereological) study of the effects of vasectomy on spermatogenesis in rabbits. Journal Anatomy. 205: 147-156.

8 Kumar V. \& Raj A. 2012. No-scalpel vasectomy by eletrocauterization in free range rhesus macaques (Масаса mulatta). Open Veterinary Journal. 2: 6-9.

9 Liu J., Rong C.T., Li Y., Liu X.X., Wang W.T. \& Li N. 2014. Vasectomy induces oxidative stress and up-regulates the expression of peroxiredoxins in mouse testis in short and early periods after surgery. Journal of Urology. 191(6): 1920-1926.

10 Lourenço R.F.S., Dias R.S. \& Gomes A.P.A. 2008. Criação de paca (Agouti paca) como alternativa de diversificação de produção e renda em Minas Gerais. In: Proceedings of XLVI Congresso da Sociedade Brasileira de Economia, Administração e Sociologia Rural (Rio Branco, Brasil). p15.

11 Ma L., Guo Y., Yuan Y., Li Y.G., Deng X.Z. \& Yang Z.W. 2015. Morphometric study of the testis and reproductive tract (including sperm granuloma) after vasectomy in mature rats. Asian Journal of Andrology. 17(3): 513-515.

12 Menezes D.J.A., Carvalho M.A.M., Assis-Neto A.C., Oliveira M.F., Farias E.C., Miglino M.A. \& Medeiros G.X. 2003. Morfologia dos órgãos genitais externos do macho de cutia (Dasyprocta aguti, Linnaeus, 1766). Brazilian Journal of Veterinary Research Animal Sciense. 40(2): 148-153.

13 Pachaly J.R., Acco A., Lange R.R., Nogueira T.M.R., Nogueir M.F. \& Ciffoni E.M.G. 2001. Order Rodentia (Rodents). In: Fowler M.E. \& Cubas Z.S. (Eds). Biology, medicine, and surgery of south american wild animals. Ames: Iowa State University Press, pp.225-237.

14 Peng B., Mao Y., Tang X.F., Shang Y., Shen C.Y., Guo Y., Xiang Y. \& Yang Z.W. 2011. Comparison of spermatogenic damage induced at 6 months after ligation of the vas deferens at proximal and distal locations in the rabbit. Andrologia. 43: 129-138.

15 Queirolo D., Vieira E., Emmons L. \& Samudio R. 2008. Cuniculus paca. In: 2008 IUCN Red List of Threatened Species. Versão 2015.2. Disponível em <http://www.iucnredlist.org/details/699/0>. [Accessed online June 2015].

16 Redford K.H. \& Robinson J.G. 1991. Neotropical wildlife use and conservation. Chicago: University of Chicago Press, $538 \mathrm{p}$.

17 Rival C., Wheeler K., Jeffrey S., Qiao H., Luu B., Tewalt E.F., Engelhard V.H., Tardif S., Hardy D., Rio R., Teuscher C. \& Tung K. 2013. Regulatory T cells ads vasectomy. Journal of Reproduction Immunology. 100(1): 66-75.

18Salman M.O., Al-Wasiti E.A., Thamir K.A., Al-Ani I.M. \& Al-Salihi A.R. 2012. The effects of vasectomy on testicular tissue of mice: histological changes and DNA fragmentation study. The International Medical Journal Malaysia. 11(2): 1-7.

19 Teixeira R.H.F., Paz R.C.R. \& Guimarães M.A.B.V. 2003. Vasectomia como ferramenta para o manejo reprodutivo em macaco-prego (Cebus apella). In: proceedinsg of VII Congresso e XII Encontro da ABRAVAS (São Pedro, Brasil). 1 CD-ROM.

20 Tung K.S., Teuscher C., Goldberg E.H. \& Wild G. 1981. Genetic control of antisperm utoantibody response in vasectomized guinea pigs. Journal of Immunology. 127(3): 835-839. 